\title{
Mycology and mycotechnology on postal stamps
}

\author{
Vandana Ghormade, Ejaj Pathan, Jeevan Jyoti, Ajit Vartak and Mukund Deshpande*
}

Mycology, the study of fungal biology, and philately, the study of postage stamps, are rarely connected, as they are very different activities. However, philatelic mycology can raise awareness of the facets of fungi which contribute significantly to human welfare. Fungi are photogenic and exhibit physiological wonders such as luminescence. They are important in biotechnology for their secondary metabolites. So, stamps depicting fungi signal the recognition of problems and prospects of prosperity posed by fungi in nutrition and health, agriculture, engineering, industry and ecology. Many countries have issued thousands of stamps on fungi. India with a rich heritage of fungal diversity lags in this respect. This article hopes to inspire action by celebrating the beauty and significance of fungi in the art of philately.

Keywords: Mycotechnology, mycology, mycophilately, photogenic appeal, postal stamps.

PHILATELY is the collection, study and appreciation of stamps and related items. It includes research on stamps and other philatelic products. Proctor ${ }^{1}$ suggested using philately in geography teaching. Senanayake ${ }^{2}$ used philately to promote paediatrics, especially in priority areas. Bandopadhyay ${ }^{3}$ described food and nutrition education through philately. Zagkotas and Niaoustas ${ }^{4}$ used philately as a teaching aid by implementing a project in a Greek primary school. As a teaching aid, it is useful for classifying flora and fauna, and to understand their evolution, history, physiology, discoveries and applications. Luther ${ }^{5}$ extensively studied postal stamps, old postcards and other postage materials showing fungi. However, mycophilately was largely neglected till a monumental book, Philatelic Mycology: Families of Fungi in 2014 by Marasas et al. ${ }^{6}$ found favour with both stamp-collectors and mycologists.

Though many countries have now released stamps with mushrooms in natural environments, there is no standardized cataloguing. Stamp collectors in the United Kingdom use the Stanley Gibbons Catalogue of Postage Stamps. However, the Scott Postage Stamp Catalogue is more popular. Though India refers to both catalogues, it

\footnotetext{
Vandana Ghormade is in the Department of Nano Bioscience, Agharka Research Institute, Pune 411 004, India; Ejaj Pathan is in the Department of Biosciences and Bioengineering, Indian Institute of TechnologyBombay, Powai, Mumbai 400 076, India; Jeevan Jyoti is in the PCCF Office, HP Forest Department, Talland, Shimla 171 002, India; Ajit Vartak is in the Department of Geology and Petroleum Technology, Wadia College, Pune 411 001, India and Mukund Deshpande is in the Biochemical Sciences Division, CSIR-National Chemical Laboratory, Pune 411 008, India.

*For correspondence. (e-mail: mvdeshpande1952@gmail.com)
}

has no stamp depicting fungi. In this article, we deal with the significance of fungal organisms and the need for mycophilately. We also highlight attempts by many countries to promote mycophilately.

\section{Importance of fungi}

Fungi are eukaryotes, like plants and animals. The main distinguishing feature is the structural component of the fungal cell wall - chitin - a polymer. This makes fungi different from plants, which have cellulose in the cell wall. Another feature of fungi that distinguishes them from other eukaryotes is their typical nuclear division, where the nuclear membrane remains intact during mitosis. Fungi are the second largest group of species on earth after insects. There are more than 81,000 known fungal species and recent assessments suggest that the estimated number of fungal species on earth could be 5.1 million $^{7}$. They usually outnumber plants 6 to 1 . Moreover, their physiological activities render fungi model systems in developmental studies and in biotechnology. The first applications of fungi were reported in 2000 BC from Egypt, China and Sumeria. In ancient times people used yeast, maybe unknowingly, for bread leavening and beer or wine fermentation. Today, fungi have a wide range of applications from single-cell protein production, as biosensors, and in cancer therapy to electricity generation. They play significant roles in all subdivisions of biotechnology: red (e.g. antibiotic production), white/grey (e.g. organic acid fermentation), green (e.g. mushroom cultivation, mycoinsecticides) and blue (e.g. oil pollution bioremediation in marine environments). Yet fungi are 
neglected for various reasons, including the historical dilemma about their positioning with respect to other eukaryotes.

\section{Framing fungi in stamps}

Most fungi are microscopic, but the reproductive structures that appear as a signature of the mushroom species are easily visible. Several countries have released stamps on mushrooms as they are photogenic. For instance, the edible parasol mushroom, Macrolepiota procera (or Lepiota procera) appears on stamps as a prominent fruiting body resembling a light umbrella ${ }^{8}$. In 2008, the Irish post released four stamps of fungi featuring the parasol mushroom. The first fungus that appeared on a Romanian stamp, in 1958, was also M. procera. Soon after, Czechoslovakia and Poland released sets of mushroom stamps ${ }^{9}$. Eventually, several countries issued stamps using mushroom-like fungi as a theme. In 1973, Bhutan issued a commemorative 3D set of mushrooms and mushroom-like fungi that remain world renowned in the philately community for their colourful creativity. Though some mushroom stamps are unfamiliar and, therefore, incomprehensible without legends, they are a major revenue generator for Bhutan ${ }^{10}$. In 2002, New Zealand chose six species, Aseroe rubra, Entoloma hochstetteri, Hericium coralloides, Hygrocybe rubrocarnosa, Ramaria aureorhiza and Thaxter ogasterporphyreus (Cortinarius porphyroideus), for first day covers and miniature sheets, to display the wonderful diversity of indigenous bracket fungi, cup fungi, jelly fungi and puff ball fungi. The description of fungi raises awareness about their phenotypic specialties, origin and unique features. For example, T. porphyreus has a unique mechanism of dispersing spores. Instead of opening the mushroom cap to disperse spores, it attracts insects and birds which feed on the caps, consume spores and distribute them through droppings. A. rubra resembles a sea anemone and its spores are produced in slimy mucus at the centre. The striking blue-coloured E. hochstetteri, the most vivid and impressive $H$. rubrocarnosa, the coral fungus $R$. aureorhiza, and the spiny, much-branched icicle fungus $H$. coralloides were also selected for their unique photogenic appeal ${ }^{11}$. The New Zealand Reserve Bank launched banknote designs in the late 1980 s, featuring blue E. hochstetteri on the $\$ 50$ note. This was retained in 2014 due to the perseverance of a mycologist, Peter Buchanan (https:// sporesmouldsandfungi.wordpress.com/2014/07/12/hochstetters-blue-pinkgill/). Further, it is suggested that the kōkako bird probably got its blue wattles from rubbing on the little blue mushroom and, therefore, it also shares space on the same US\$ 50 note $^{11}$. In 2008, the Netherlands released attractive stamps of Amanita muscaria, Clathrus archerii, Coprinus comatus, Cyathus striatus and Geastrum triplex to coincide with the 100th year of the Netherlands Mycological Society. A sheetlet titled 'Experience nature-mushrooms' was released in 2018. The process and criteria used to select only ten mushrooms out of the 5000 species found in Dutch soils are a unique example of taking into account the diversity, biology and photogenic appeal of fungi ${ }^{12}$ (Table 1). An example is bonnet mould, Spinellus fusiger, a sporangiospore-forming fungus which is a parasite on a number of mushrooms. Figure 1 presents such a case on Mycena hematopus.

In 2018, the US released stamps of bioluminescent life. In addition to eight bioluminescent organisms from oceans, two land-based species (mushroom and firefly) were also featured $^{13}$. For mycophilately, this was indeed a breakthrough. The US Post Office Department was established in 1792 and it took 226 long years to release a stamp on fungi, after constant petitioning from researchers. Previously, mushrooms were represented on stamps as part of larger forest scenes, but not individually. Mycena lucentipes, a mushroom capable of producing light through yellow-green bioluminescence, is one of the species that appears on the stamp. There are more than 80 species of mushrooms capable of emitting light, and helpful in attracting insects that spread the mushroom spores. Earlier, countries like Romania, the Solomon Islands, Vietnam, Indonesia and Malaysia released postal stamps on bioluminescent fungi ${ }^{14}$. Interestingly, Armillaria mellea appeared on a Romanian postage stamp in 1958 not for the distinctive bioluminescence, but as edible mushroom. Malaysia, on the other hand, has a postal stamp of an unidentified and non-luminescent fungus marked as bioluminescent. The Mayotte Island in the Mozambique Channel, is trying to preserve fungal biodiversity through philatelic promotion of the photogenic features of different fungal fruit bodies. In 2007 and 2010, Peru issued two sets of mushroom stamps. The 2007 set was indented on a mushroom-shaped souvenir sheet ${ }^{15}$. It is not only the artistic and design criteria, but also their biology that make fungi suitable candidates for postal stamps. Other releases were the orange birch bolete (Leccinum versipelle), representing the fungusplant relationship, pink wax cap (pink ballerina, Hygrocybe calyptriformis) as an indicator species for habitat loss and scarlet elf cup (Sarcoscypha austriaca) which ejects a puff of spores with a 'puffing' sound ${ }^{8}$. One of the first stamps on fungi was about mycotechnology, an indirect depiction of yeast which produces ethanol ${ }^{9}$. To celebrate the tenth anniversary of the alcohol industry, the Japanese Government issued a stamp with a line of budding yeast at the bottom ${ }^{10}$.

\section{Edible mushrooms}

A number of edible mushrooms have appeared on postal stamps released from different countries (Table 1). For 
Table 1. Fungi on stamps

\begin{tabular}{l} 
Fungus \\
\hline Photogenic appeal (structural features/uniqueness) \\
Armillaria melleo, Astraeus hygrametricus, Boletus edulis, Hyphalama fasciculare, \\
$\quad$ Sarcoscypha caccinea \\
Aseroe rubra, Entoloma hochstetteri, Hericium coralloides, Hygrocybe rubrocarnosa, \\
$\quad$ Ramaria aureorhiza, Thaxterogaster porphyreus \\
Entoloma hochstetteri (on stamps as well as on currency notes) \\
Amanita muscaria, Clathrus archerii, Coprinus comatus, Cyathus striatus, Geastrum triplex \\
A. muscaria (fly amanita), Clavaria argillacea, Marasmiellus ramealis (twig parachute), \\
$\quad$ Mycena haematopus (bleeding fairy helmet), Plicaturopsis crispa (crimped gill), Pterula multifida, \\
Russela fragilis (fragile brittlegill), Sparassis crispa (caulifolower fungus), Spinellus fusiger \\
(bonnet mould), Stropharia aeruginosa (Verdigris agaric)
\end{tabular}

Macrolepiota procera or Lepiota procera (parasol mushroom)

Edible mushrooms (some of the genera, species or strains can be poisonous)

M. procera, Russela virescens

B. edulis, Macrolepiota rhacodes

Flammulina velutipes, Kuehneromyces mutabilis, Lyophyllum connatum, Lyophyllum decastes

Cantharellus cinerus, Hydnum repandum, Lactarius torminosus, Rozites caperatus

Agaricus silvaticus, Amanita caesarea, Armillariella mellea, B. edulis, Lactarius deliciosus,

Macrolepiota procera, Pleurotus ostreatus, Suillus grevillei (imperforated stamps)

Amanita rubescens, Boletus regius, C. cibarius, Coprinus comatus, Leccinum aurantiacum,

Russula vesca

Trametes versicolor

Amanita panterina, A. muscaria, A. caesarea, Coprinus micacius, C. comatus,

Gymnopilus spectabilis, Hebeloma crustuliniforme (some of them are poisonous)

Boletus mirabilis, C. cinnabarinus, Clavulinopsis fusiformis, Morchella esculenta

Leucocoprinus africanus, Phlebopus sudanicus, Psalliota sebedulis, Synpodia arborescens,

Termitomyces schimperi, T. entolomoides, T. microcarpus, T. aurantiacus,

T. mammiformis, Tremella fuciformis, Volvaria esculenta, A. caesarea, Lentinus cubensis,

Pleurotus levis, Pleurotus floridanus, P. ostreatus, Coprinus comatus, Cortinarius cumatilis,

Clitocybe infundibuliformis, Pholiota caperata, Lactarius deliciosus, Morchella elata,

Pleurotus eryngii var. ferulae, Sparassis crispa

A. rubescens, Leccinum rufescens

Lactarius torminosus, Leccinum versipelle, Russula paludosa

Chanterelle violette, Lactarius indigo, Russula palomet (Agaricus palomet)

(first day cover with cancellation stamp)

Agaricus campester, B. edulis, B. erythropus,

B. edulis, C. cibarius, Leccinum scabrum, Xerocomus badius

Morchella esculenta

Amanita groenlandica, Lecinnum species, Russula subrubens

Calvatia cretacea, Lactarius dryadophilus, Rozites caperata

Amanita phalloides (death cap)

B. edulis, Russela xerampelina (12 mushroom stamps from 1999-2012)

Termitomyces letestui, T. schimperi

T. schimperi

Leccinum scabrum, Morchella conica, Pleurotus eryngii, Pleurotus ostreatus

Boletus radicans, Gomphus clavatus (pig's ear mushroom)

Termitomyces eurrhizus

Macrolepiota procera (slightly toxic when eaten raw), Tricholoma fulvum

Volvariella bombycina, Morchella anteridiformis, Lentinus tuber-regium

Pleurotus cornucopiae, Catathelasma ventricosum, Pleurotus ostreatus

Lactarius deterrimus, Lepista nuda

Amanita phalloides, A. muscaria, Boletus luteus, B. edulis, Boletus scaber, Cantharellus cibareus,

Lactarius deliciosus, Psalliota campestris (not all are edible)

Auricularia polytricha, Lentinus edodes, Pleurotus sajor-kaju, Vovariella volvacea

Comoro Islands (1985)

New Zealand (2002)

New Zealand (2014)

The Netherlands (2008)

The Netherlands (2018)

Romania (1958), Czech

Republic (1958), Poland (1959),

Malawi (2008)

Japan (1974)

Afganistan (1996)

Armenia (2013)

Belarus (1999)

Belarus (2013)

Bulgaria (1961)

Bulgaria (1987)

Cameroon (1975)

Cambodia (1985)

Canada (1989)

Central African Republic (1967)

Congo (1970)

Cuba (1989)

Cuba (2002)

Cuba (2005)

Cyprus (1999)

Czech Republic (2018)

Finland (1980)

France (1987)

Germany (1980)

Germany (2018)

Ghana (2015)

Greenland (2005)

Greenland (2006)

Hungary (1986)

Iceland (2012)

Ivory Coast (1995, 1998)

Kenya (1989)

Kyrgyzstan (2017)

Lietuva (2016)

Malawi (1985)

Malawi (2008)

New Caledonia (1998)

North Korea (1985)

Norway (1988)

Poland (1959)

Phillipines (1988) 
GENERAL ARTICLES

Table 1. (Contd)

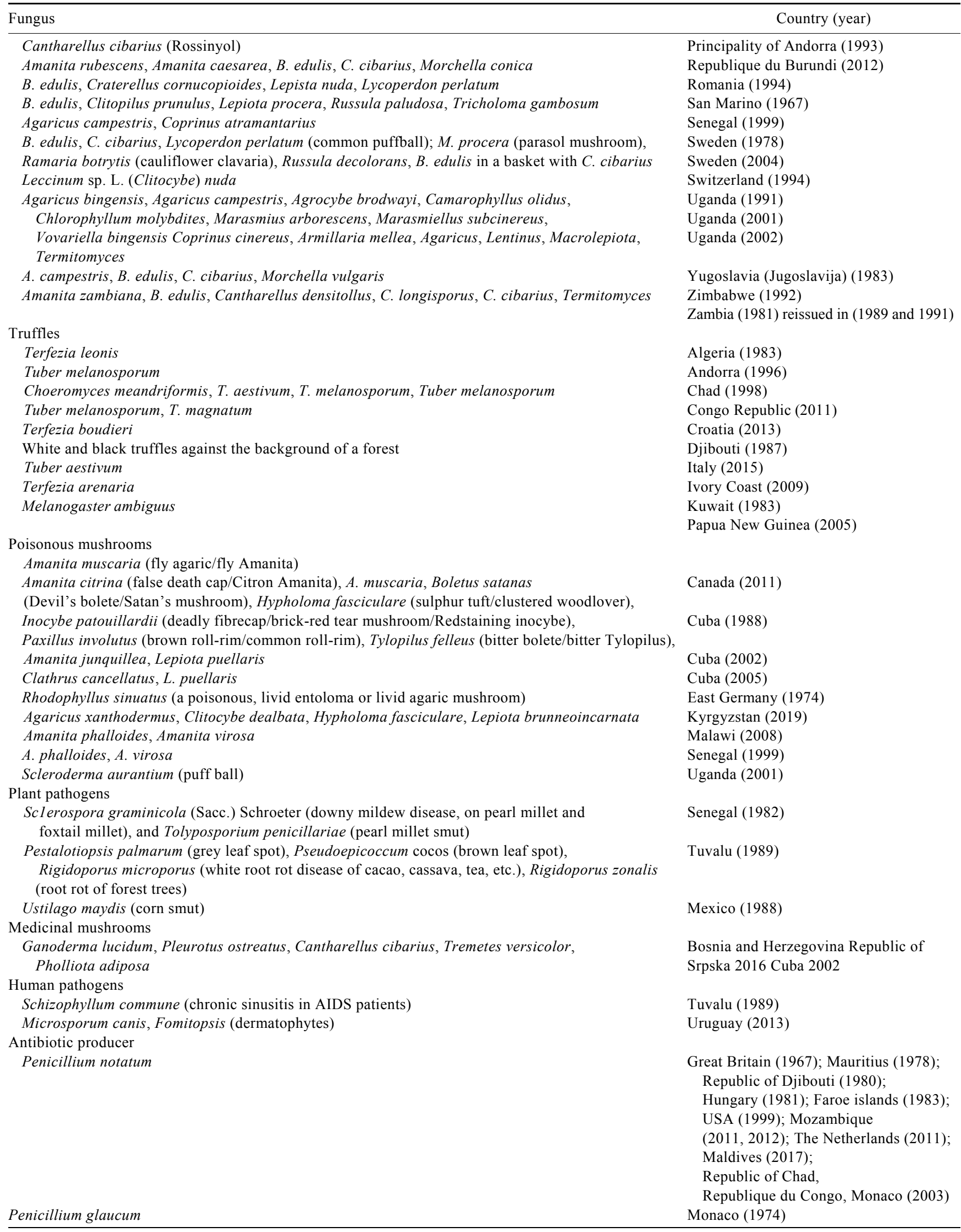


Table 1. (Contd)

\begin{tabular}{|c|c|}
\hline Fungus & Country (year) \\
\hline \multicolumn{2}{|l|}{ Pollution indicator; indicator for sulphur dioxide pollution } \\
\hline String-of-sausage lichen Usnea articulate & $\begin{array}{l}\text { Self-Governing British Crown } \\
\text { Dependency, Mann (1986) }\end{array}$ \\
\hline Santessonia sp. & Namibia (2008) \\
\hline Hypogymnia physodes, Xanthoria parietina & Finland Aland (1999) \\
\hline \multicolumn{2}{|l|}{ Fermentation } \\
\hline Zlaty bazant (golden pheasant) - Dark Yeast Beer & Slovakia (2011) \\
\hline Trametes muelleri and Trametes cingulata (lignin hydrolysing enzymes) & Tuvalu (1989) \\
\hline \multicolumn{2}{|l|}{ Chitosan production } \\
\hline Benjaminiella poitrasii (Cancellation stamp) & India (2018) \\
\hline \multicolumn{2}{|l|}{ Bioluminescence } \\
\hline Mycena lucentipes (edible?) & USA (2018) \\
\hline \multicolumn{2}{|l|}{ Cheese } \\
\hline Penicillium roqueforti (Roquefort), Penicillium camemberti (Camembert) & Canada (2006) \\
\hline Penicillium roqueforti (Roquefort) & France (2006) \\
\hline \multicolumn{2}{|l|}{ Mycologists } \\
\hline Michel Adanson (Microlepiota procera), Alexander Fleming (Penicillium notatum) & Union des Comores (2008) \\
\hline Edward Fischer (Phallus impudicus), Charles Edwin Bessey (Armillariella mellea), & \\
\hline Peter Adolph Karsten (Marasmius oreades), Charles Horton Peck (Chroogomphus vinicolor), & \\
\hline Andrea Cesalpino (Tricholoma flavovirens), Miles Joseph Berkeley (Paxillus involutus), & \\
\hline $\begin{array}{l}\text { H. Anton de Bary (Boletus lupines), A. H. R. Buller, J. B. Ellis (Agaricus peziza sp.), F. J. Seaver, } \\
\text { R. G. Wasson }\end{array}$ & Central African Republic (2012) \\
\hline
\end{tabular}

Compiled from refs $10,17,22,25,26,33-35$.

instance, in 1999 and 2013, Belarus released Cantharellus cinereus and other species rich in antioxidant carotenoids such as $\beta$-carotene, canthaxanthin and vitamin $\mathrm{D}$. Hydnum repandum, also known as sweet tooth or hedgehog fungus, is widely marketed in Europe, Mexico and Canada. Lactarius torminosus is a big agaric fungus widely known as woolly milkcap mushroom. It tastes acrid and may be toxic if eaten raw. In 1989, Canada released stamps depicting Boletus mirabilis, C. cinnabarinus, Clavulinopsis fusiformis and Morchella esculenta. Some species such as M. esculenta, though edible, are a gastrointestinal irritant if not cooked. Cuba published mushroom stamps in 1989, 2002 and 2005, including Pleurotus ostreatus, a pearl oyster mushroom, originally grown in Germany during the First World War. This fungus is also useful for mycoremediation, and making mycelia bricks and myco-furniture. Haneef et $a l .{ }^{16}$ described the fabrication and tuning of physical properties of advanced materials from two mushrooms, P. ostreatus and a medicinal fungus, Ganoderma lucidum $^{16}$ (Table 1). The largest edible mushroom in the world is a species of Termitomyces, T. titanicus, which has a cap that is $3 \mathrm{ft}$ in diameter. It is found in West Africa and Zambia. In 2007, this fungus appeared on a souvenir sheet issued by the Postal Department of the Republic of Guinea. Interestingly, the postage stamp depicting a barn owl and A. muscaria together, is categorized as MID. However, outer portion of the souvenir sheet shows a person holding T. titanicus ${ }^{17}$. As pointed out by Luther ${ }^{17}$, the fungus is misidentified as Boletus edulis.

\section{Truffles}

A truffle is a round, warty fungal fruiting body which develops underground. Interestingly, truffles cannot be cultivated, but farmers plant specific trees and truffles grow near their roots. There appears to be a symbiotic relationship between the mycelia of truffles and the roots of tree species such as beech, birch, hornbeam, hazel, oak, pine and poplar. Before the First World War, France produced as many as 1000 tonnes of edible truffles. Kuwait was the first country to release a postal stamp of Terfezia in 1983, as part of a set depicting 50 desert plants and fungi from Kuwait (Table 1). As the scientific names are missing on the stamps, Terfezia species was suggested to be either T. arenaria or T. leonis $^{18}$. A small nation, Andorra, was the first European country to issue a truffle, Tuber melanosporum, on a stamp in 1996. The Congo Republic issued three mushroom stamps in 2011 and a truffle $T$. melanosporum was depicted outside on the sheet. Surprisingly, the species on the stamp is not found in the Republic of Congo ${ }^{18}$.

\section{Poisonous mushrooms}

The Postal Department of the Kyrgyz Republic strategically released stamps of edible mushrooms ${ }^{19}$ in 2017 and poisonous mushrooms ${ }^{20}$ in 2019 (Table 1). The Department expressed the hope that these stamps would contribute to spreading knowledge about mushrooms and help protect these remarkable representatives of Kyrgyzstan's 


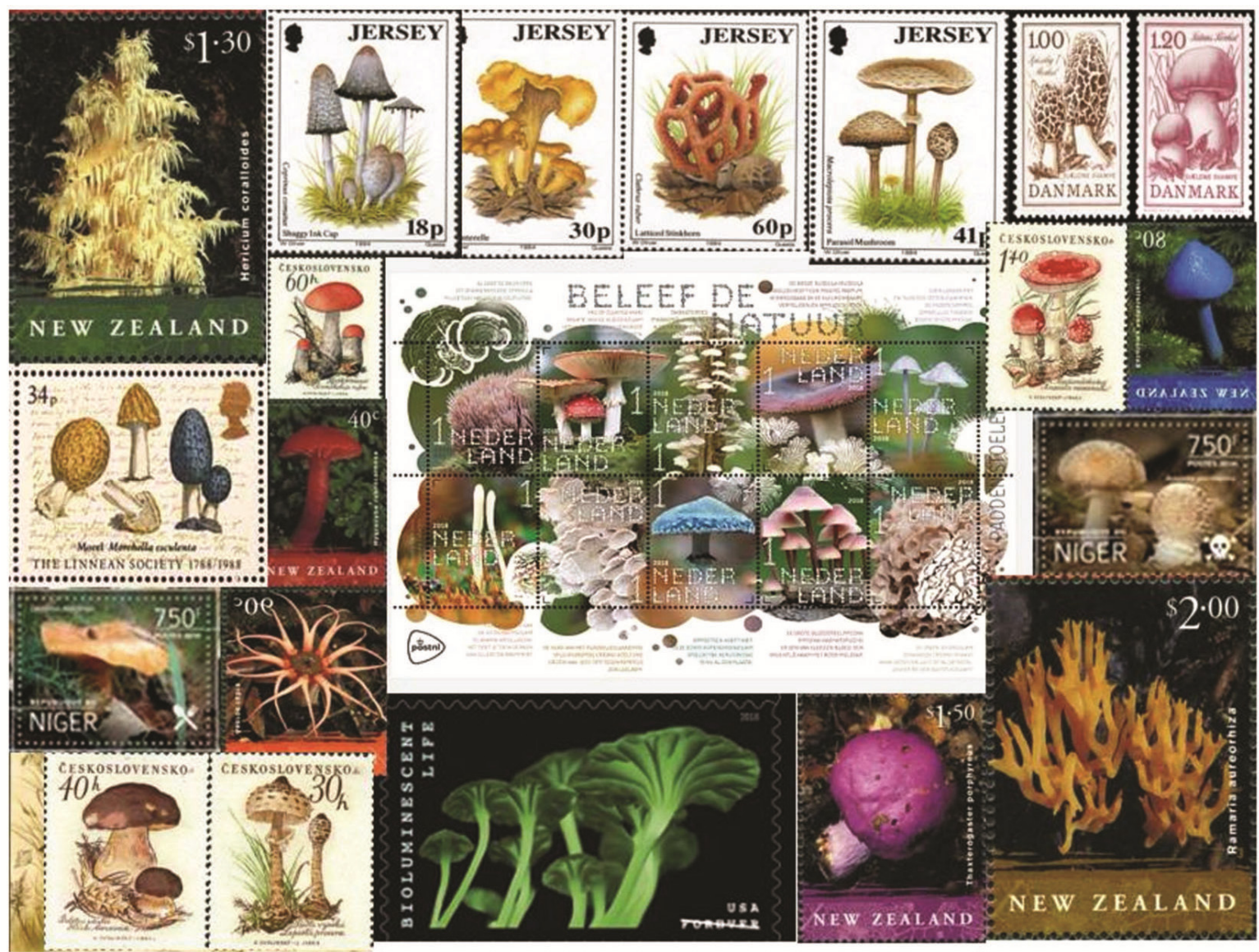

Figure 1. Different mushrooms on the postal stamps.

biodiversity. The official first day cover was also released with Agaricus xanthodermus as cancellation stamp. It was emphasized that mushrooms, both edible and poisonous, are important in ecological systems and therefore need protection. The genus Amanita consists of approximately 600 species, some edible and some extremely toxic (reportedly causing $>90 \%$ fatalities due to mushroom poisoning; Table 2). The $\alpha$-amanitin is a potent toxin present in these mushrooms. In 1974, the then East Germany dedicated stamps to poisonous mushrooms, not only for their beauty, but also to raise awareness. Cuba released stamps of poisonous mushrooms ${ }^{10}$ in 1988 and in 2005, a set titled 'Hongos y Polimitas', mushrooms and snails - an unusual combination. Four mushrooms, Clitocybe infundibuliformis and Pholiota caperata (edible) and Clathrus cancellatus and L. puellaris (poisonous) were described, but $P$. caperata was not depicted on the stamp (Table 1). In 1995, Malaysia released stamps of four mushrooms: Microporus xanthopus, Cookeina tricholoma, Dictyophora phalloidea and Ramaria sp. Luther $^{21}$ suggested that according to Ronald H. Petersen, Ramaria sp. could be $R$. polypus, thus highlighting the importance of stamps in taxonomy too. Figure 1 depicts some of the mushrooms.

\section{Infections and treatments}

In 1997, Uruguay issued the first ever official postage stamp showing a human fungal pathogen, a dermatophyte, Microsporum canis ${ }^{22}$. The stamp depicts a dog, natural host to the pathogen, being hugged by a girl, and an inset with a microscopic view of an infected human hair with distinctive spores of the pathogen. Though fungi cause many diseases, some quite difficult to treat, there not many examples of philatelic recognition of the problem. However, fungi as sources of medicine seem to be better appreciated. Penicillium chrysogenum, a mould commonly found indoors, is involved in food spoilage. This genus came into limelight because of the accidental discovery by Alexander Fleming of the antibacterial activity of $P$. rubens, formerly known as $P$. notatum (Fleming species, member of $P$. chrysogenum complex $)^{23}$. During the Second World War, penicillin became a wonder drug, reducing the number of deaths and amputations. Penicillium appeared on the postal stamps of many countries. The first US postage stamp with a scanning electron microscope image of Penicillium, issued in 1999, was artificially coloured. Penicillium roqueforti and Penicillium glaucum are used for producing blue cheese, 
Table 2. Diversity in the genus Amanita

\begin{tabular}{lll}
\hline Edible Amanita species & \multicolumn{1}{c}{ Toxic Amanita species } & \multicolumn{1}{c}{ Deadly poisonous species } \\
\hline A. fulva, & A. brunnescens, & A. abrupta, \\
A. vaginata, & A. ceciliae, & A. arocheae, \\
A. calyptrata, & A. cokeri (Coker's amanita), & A. bisporigera (eastern NA destroying angel), \\
A. crocea, & A. crenulata, & A. exitialis, \\
A. rubescens, & A. farinosa (eastern American floury amanita), A. magnivelaris, \\
A. caesarea, & A. frostiana, & A. ocreata, \\
A. jacksonii, & A. flavorubescens, & A. phalloides, \\
A. zambiana and A. citrina & A. muscaria, & A. smithiana, \\
& A. pantherina and A. porphyria & A. subjunquillea,, \\
& & A. verna and A. virosa \\
\hline
\end{tabular}

flavouring agents, antifungals, polysaccharides, proteases and other enzymes. These fungi are well known for producing cheese varieties like Roquefort, Stilton, Danish blue, Cabrales and Gorgonzola. In 2006, the Canadian Postal Service published stamps that display a cheese wheel coated with $P$. roqueforti or $P$. camemberti. The stamps were designed and shaped like cheese labels ${ }^{24}$.

\section{Plant pathogens}

In 1982, Senegal released a set of stamps depicting Sclerospora graminicola, the causative agent of the downy mildew disease on pearl millet and foxtail millet and Tolyposporium penicillariae, the smut fungus infecting pearl millet ${ }^{25}$. The pests infesting pearl millet, Arnsacta moloneyi and Raghewa albipunctella, also appear on the stamps $^{25}$. In 1989, Tavalu released stamps with photographs of the pathogenic lesions caused by Pestalotiopsis palmarum (grey leaf spot), Pseudoepicoccum cocos (brown leaf spot), Rigidoporus microporus (white root rot disease of cacao, cassava, tea, etc.), and Rigidoporus zonalis (forest tree root rot). The first fungal stamp depicting corn smut causing Ustilago maydis is from Mexico $^{26}$ (Table 1). Though there are many fungi that are useful for crop productivity and crop protection, they have not yet been popularized through stamps.

\section{Symbiotic mushrooms}

Almost 30-40 species of the genus Termitomyces are dependent on termites for survival. Termitomyces mushrooms produce various enzymes to help termites digest lignocellulosic substrates. This genus appears on the postal stamps of a number of countries such as the Ivory Coast, Kenya, Malawi, Uganda and Zimbabwe (Table 1).

\section{Pollution indicator}

Lichens are important sulphur dioxide pollution indicators. Self-Governing British Crown Dependency, Mann, released a stamp of Usnea articulate Hoffm., an Ascomycota fungus, also known as the string-of-sausage lichen, a pale greenish-grey, densely branched lichen with a pendent growth form. One of the areas in Mann, i.e. Ayres, has a specific biodiversity of rare lichens like $U$. articulate $^{25}$. In 2008, the Postal Service of Namibia released a stamp of lichen, Santesonnia sp. along with Xanthoria sp. In 1999, Finland Aland depicted Hypogymnia physodes and Xanthoria parietina on postal stamps (Table 1).

Different countries have fungal postal stamps for a variety of reasons and there are thousands of such stamps. It is difficult to list all. Table 1 describes some of them. The corticioid fungi, an attractive but neglected group, are seen on the undersides of dead tree trunks or branches. For example, cobalt blue Terena caerulea, bright-red Phanerochaete sanguinea, wine-red Cytidia salicina, yellow hydnoid Mucronella flava and greenblue Byssocorticium atrovirens are reported from different countries. In 2013, a stamp depicting $T$. caerulea inhabiting hard wood was released by Macedonia ${ }^{27}$. Figure 2 gives a general overview of some fungi with different applications and their diverse roles in nature.

\section{Fungi in ecotourism}

In 1989, Tuvalu, formerly Ellice Islands, an island country located midway between Hawaii and Australia, promoted ecotourism by releasing a set of commemorative stamps featuring Ganoderma appalantum (antioxidant and flavour compounds), R. microporus (white root rot disease of cacao, cassava, tea, etc.), $R$. zonalis (forest tree root rot), Pestalotiopsis palmarum (grey leaf spot), P. cocos (brown leaf spot) and Schizophyllum commune (omnipresent, industrially important, model organism for developmental studies and opportunistic pathogen in AIDS patients), Trametes muelleri and Trametes cingulata (a number of species are important for lignin hydrolysing enzymes). For reasons unknown, it is indicated that though stamps are available, they will not be posted to India $^{28}$.

\section{Mycologists on postal stamps}

Alexander Fleming has extensively appeared on stamps from several countries around the globe, except India and 


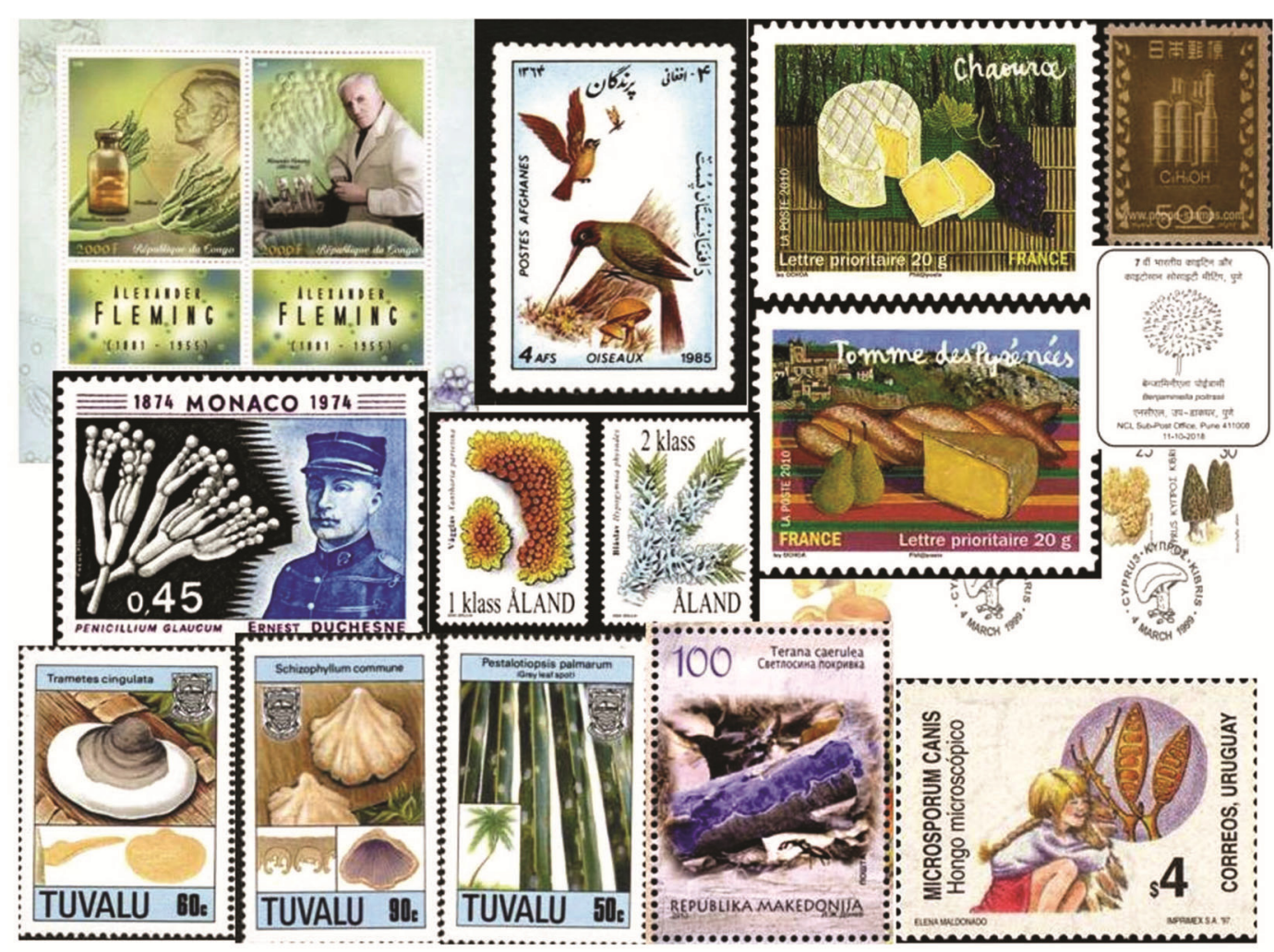

Figure 2. Fungi with different roles and applications on postal stamps.

a few others countries (Figure 2). In 1978, Mauritius released a stamp set commemorating Fleming's discovery of the antibacterial activity of Penicillium. Later, commemorative stamps were released by several African countries: Guinea and Mozambique in 2002, St Thomas in 2003 and Prince Islands in 2007.

Mycologists who spent their lives studying fungi have been commemorated in 2011 issues from the Central African Republic ${ }^{10}$. These include William A. Murrill, an American mycologist who worked on agarics and polypores; Fred J. Seaver, an American expert on discomycetes, A. H. R. Buller (British-Canadian mycologist), and Elsie Maud Wakefield, English mycologists and plant pathologists, and Anton De Bary (Germany), father of modern mycology and plant pathology. In 2011, GuineaBissau commemorated Christiaan Hendrik Persoon, another founding father of mycology. A portrait and a brief biography of Louis Pasteur appeared on a souvenir sheet issued in 2006 by the Democratic Republic of Congo. Earlier, in 2002, the country released three stamps commemorating three Nobel Prize winners in Chemistry, each with a distinct (unidentified) fungus (Table 1).

\section{Epilogue}

Fungi on stamps from different countries were compiled in 2012 by David Moore ${ }^{29}$. However, neither in his data nor in searches made later, was a single fungus stamp found from India. Some attempts have been made to release at least a special postage cover for fungi. A special cover was released in October 2015 to mark the Asian Mycological Congress held in Goa under the aegis of the Asian Mycological Association and the Mycological Society of India. Fungi are also a major source of chitin and, therefore, during the seventh Indian Chitin and Chitosan Society Meeting held at CSIR-National Chemical Laboratory (NCL), Pune in 2018, a special cover was released depicting fungi as a source of $\operatorname{chitin}^{30,31}$. The cancellation stamp was of Benjaminiella poitrasii, a zygomycetous fungus as a chitosan source with commercial potential. India has one of the world's richest fungal diversity. Fungi with the potential to be featured on postage stamps include Termitomyces, an edible mushroom from Goa; Metarhizium, an insect pathogenic fungus used as mycoinsecticide in agriculture; Trichoderma, a highly rated biocontrol and biofertilizer organism, and smut and rust-causing plant pathogens. Xylaria hypoxylon, a luminescent fungus found on dead wood in the Western Ghats, can also be a candidate. Subramanian ${ }^{32}$, reviewed the progress and status of mycology in India, since E. J. Butler arrived in 1901 to energize mycology and mycotechnology. Today, India has two mycology societies: the Mycological Society of India and the Indian Society for Mycology and Plant Pathology, functioning since 1973 and 1970 respectively. A number of other societies also deal with fungi and fungal metabolites. In spite of such a 
long history and wide following, the Indian Post has not issued any postage stamp on mushrooms or any other fungus so far, and not a single Indian mycologist appears on a postal stamp. One reason could be the lack of awareness of the significance of philately in education, research and in spreading knowledge. Or should we attribute it to the apathy and lack of perseverance of Indian mycologists?

Conflict of interest: The authors declare no conflict of interest.

1. Proctor, N., Philately and geography teaching. Geogr. L., 1965, 50, 134-141.

2. Senanayake, M. P., Paediatric philately. Arch. Dis. Childhood, 1997, 76, 287-288.

3. Bandyopadhyay, M., Food and nutritional education through the world of philately. J. Agric. Eng. Food Technol., 2017, 4, 71-74.

4. Zagkotas, V. and Niaoustas, G., Philately as a teaching aid through the implementation of a small-scale project in a Greek primary school. Education, 2020, 48, 3-13.

5. Luther, B. S., The earliest postage stamps with fungi. Spore Prints, 2012, 483, 4-6.

6. Marasas, W. F. O., Marasas, H. M., Wingfield, M. J. and Crous, P W., Philatelic Mycology: Families of Fungi, CBS Biodiversity Series No. 14, CBSKNAW Fungal Biodiversity Centre, Utrecht, The Netherlands, 2014, ISBN 978-90-70351-99-1.

7. Blackwell, M., The fungi: $1,2,3 \ldots 5.1$ million species? Am. J. Bot., 2011, 98, 426-438.

8. O'Connell, C., Fungi stamp their mark on post. The Irish Times, 7 August 2008

9. Ing, B., Fungi on stamps. Bull. Br. Mycol. Soc., 1976, 10, 32-37.

10. Moore, D., Fungi on stamps: introduction and references. a guide to the world of fungi on stamps and other postal ephemera, 2016; http://www.davidmoore.org.uk/Fungi-on-Stamps00.htm (accessed on 10 September 2019).

11. Spores, moulds and fungi, A mycology of New Zealand in 10 fungi; https://sporesmouldsandfungi.wordpress.com/2016/08/07/a-mycologyof-new-zealand-in-10-fungi/ (accessed on 10 September 2019).

12. Experience nature-mushrooms-miniature sheet, 2018; https:// www.wopaplus.com/en/stamps/product/\&pid=49258 (accessed on 10 September 2019).

13. Widder, E., U. S. postal service to dedicate bioluminescent life stamps, 2018; https://about.usps.com/news/national-releases/2018/ pr18_013.htm (accessed on 10 September 2019).

14. Luthar, B. S., Bioluminescent fungi on stamps. Spore Prints, 2014, 507, 4-5.

15. Luthar, B. S., Mushroom stamps from Peru. Spore Prints, 2015, 508, 7-8.

16. Haneef, M., Ceseracciu, L., Canale, C., Bayer I. S., HerediaGuerrero, J. A. and Athanassiou, A., Advanced materials from fungal mycelium: fabrication and tuning of physical properties. Sci. Rep., 2017, 7, 41292.

17. Luther, B. S., Largest edible mushroom shown on postage. Spore Prints, 2014, 502, 5-6.

18. Luther, B. S., Truffles on postage stamps. Spore Prints, 2014, 498, 4-6.

19. Edible mushrooms of Kyrgyzstan, Kyrgyz Express Post Newsl., 2017, 22, 1-3.

20. Poisonous mushrooms of Kyrgyzstan, Kyrgyz Express Post Newsl., 2019, 51, 1-3.

21. Luther, B. S., Malaysian mushroom stamps. Spore Prints, 2013, 491, 4-6.

22. Luther, B. S., Uruguay mushroom stamps show a dermatophyte. Spore Prints, 2013, 497, 4.

23. Houbraken, J., Frisvad, J. C. and Samson, R. A., Fleming's penicillin producing strain is not Penicillium chrysogenum but $P$. rubens. IMA Fungus, 2011, 2, 87-95.

24. Luther, B. S., Canadian postage \& postal items with fungi. Spore Prints, 2014, 505, 1-3.

25. Moss, M. O. and Dunkley, I. P., Recent issues of postage stamps depicting fungi. Mycologist, 1988, 2, 116-121.

26. Luther, B. S., Mycophilately in Mexico. Spore Prints, 2013, 489, 4-5.

27. Luther, B. S., Resupinate fungus shown on a postage stamp. Spore Prints, 2014, 502, 6

28. https://www.ebay.ie/itm/Tuvalu-520-523-MNH-Fungi-1989/401741176863 (accessed on 20 September 2019).

29. Moore, D. World of fungi stamp collection-David Moore's world of fungi, 2012; www.davidmoore.org.uk > stampWEB > StampWeb_full_list-2012 (accessed on 20 September 2019).

30. Deshpande, M. V., Ghormade, V. and Pathan, E. K., New special cover from Pune. Rainbow Newsletter, 11 November 2018.

31. Madhu, K. P., Coming of age: chitin chitosan research. Curr. Sci., $2018,115,1849-1851$.

32. Subramanian, C. V., The progress and status of mycology in India. Proc. Indian Acad. Sci. (Plant Sci.), 1986, 96, 379-392.

33. Luther, B. S., The first African mushroom stamps. Spore Prints, $2012, \mathbf{4 8 5}, 6-7$

34. Luthar, B. S., Icelandic mushroom stamps. Spore Prints, 2014, 506, 4-5.

35. Moss, M. O., A selection of microfungi depicted on postage stamps. Mycologist, 1992, 6, 68-71.

ACKNOWLEDGEMENTS. We acknowledge the efforts of Prof. Bernard F. Rodrigues (Goa University), for featuring fungi, for the first time in India, on a special postal cover released during the Asian Mycological Congress in 2015. We thank K. P. Madhu and Geeta Madhu for critical reading of this manuscript.

Received 26 September 2019; revised accepted 23 November 2020

doi: $10.18520 /$ cs/v120/i4/628-636 